\title{
Role and Use of Probiotics in Allergic Diseases: Review of the Literature
}

\author{
Öner Özdemir (1)
}

The prevalence of allergic diseases including atopic dermatitis has increased over the last few decades. Atopic dermatitis is a widespread allergic disease and the first step of allergic march, for which there is presently no known treatment. Under the recent literature data, use of probiotics in early life beginning from pregnancy is thought to be an effective method and appears to be a hopeful tactic for prevention, but very little is known about its long-term preventive effect. Here, our aim is to give an outline of the results from these prevention/treatment studies and to discuss current approaches. Probiotics are universally described as "live microorganisms that, when administered in adequate amounts, confer a health benefit on the host" by the World Health Organization. In most studies, single strains or a mixture of strains of lactic acid bacteria and bifidobacteria was used prenatally, postnatally, or perinatally. Several meta-analyses have shown a moderate benefit of probiotics for eczema prevention, and the most reliable effect has been observed with a combined perinatal (prenatally + postnatally) administration in infants at high risk of allergic disease by heredity. In addition, use of multi-strain (mixture of different bacterial species or of Lactobacillus species) probiotics appeared to be most effective for eczema prevention. Probiotics also could be an option in eczema therapy, especially for moderate to severe eczema in children and adults. No preventive and therapeutic effect has been shown for other allergic disorders. To date, expert bodies do not generally propose probiotics for allergy prevention, although the World Allergy Organization suggests considering using probiotics in pregnant women, during breastfeeding, and/or to the infant if at high risk of developing allergic disease.

Keywords: Allergy, allergic disease, eczema, asthma, rhinitis, probiotic

ORCID ID of the author: 0̈.0̈. 0000-0002-5338-9561

Department of Pediatric Allergy-Immunology, Sakarya University Training and Research Hospital, Sakarya, Turkey

Address for Correspondence: Öner Özdemir

E-mail: oner.ozdemir.md@gmail.com

Received: 09.06.2017

Accepted: 03.08.2017

(C) Copyright 2018 by Available online at istanbulmedicaljournal.org

\section{Introduction}

The research on probiotics, which have been called beneficial microbes since the beginning of the twentieth century, has been increasing on a daily basis, and there are approximately 2,500 articles per year related to allergy only in PubMed. The research on the effects of metabiotics, which are the metabolic residuum of probiotics in the body, has been started to be published (1). Probiotics were pre-designed for the use in different diseases according to the body needs/diseases, and designer probiotics were started to be applied (2).

First of all, we will define probiotics in this review. Then, we will briefly discuss their mechanisms of action in the human body. Their roles in the prevention and treatment of allergic diseases will be discussed in a literature review beginning with atopic dermatitis (AD). Their roles in allergic rhinitis and asthma will be explained in the light of randomized controlled trials (RCTs) and then in the light of meta-analyses and the opinions in guides.

\section{Definition of Probiotics}

They are viable microorganisms that can change the microflora of the host and can potentially show health benefits when taken orally (3). The three known characteristics of probiotics are that they are human derived, resistant to different factors in the intestinal system, and are beneficial for the host. For centuries, they have been taken into the body through fermented milk (Streptococcus thermophilus and Lactobacillus bulgaricus) (4). Today, the probiotic content is not sufficient, especially in commercial yogurt. The most commonly used and best-known probiotic bacteria are Lactobacillus and Bifidobacteria, which are lactic acid bacteria (LAB). Non-LAB species are the bacteria such as E. Coli and Bacillus, and fungi such as Saccharomyces (5).

\section{Reasons for the use of probiotics in allergies}

The hygiene hypothesis in developed countries in recent years and the increase in allergic diseases that are considered to be caused by the Western lifestyle are also characterized by the "reduction of biodiversity" in our environment and the personal differences in perinatal colonization. It is supported by the fact that the children living on farms have fewer allergic diseases $(4,5)$.

The fact that oral tolerance did not develop in mice without germ cells, but it developed with the administration of Bifidobacteria in pathogen-free mice in laboratory studies (6), and the fact that 
the efficacy of probiotics on allergic diseases was demonstrated in preliminary studies, suggested that they could be effective in these diseases and could be used for this purpose (7).

\section{Systemic Effect Mechanisms of Probiotics in Allergies}

In addition to the formation of the intestinal barrier locally, they lead to antimicrobial activity, anti-inflammatory effect, and immunomodulation. Systemic chronic (low-grade) inflammation also occurs as the result of immunomodulation. They provide this effect by enhancing the production of Th1 pathway and T regulator (Treg) cells, and by inhibiting the Th2 and Th17 pathways. The development of tolerogenic dendritic cells and the stimulation of Toll-like receptors (TLR) -2/-9 are important effects $(7,8)$.

New findings are being added to the systemic action mechanisms of probiotics every day. It has been shown in a study that it can suppress the production of histamine signaling with LAB (9). Even the modification of genetic susceptibility in childhood eczema has been shown to be achieved with one of two different types of probiotics (10).

\section{The Mechanism of Probiotic Effects on Eczema}

There is an immunomodulatory effect on the immune system cells in the skin. Competing with harmful skin microflora (Staphylococcus aureus, Herpes, fungi, etc.) and the ability to function as a protective sheath (barrier function) against harmful environmental factors are provided with a decreased skin $\mathrm{pH}$ and with the release of beneficial metabolites (11). They also have the capacity to act as anti-oxidants. All Lactobacilli, except for Lactobacillus delbrueckii, exhibit antimicrobial activity along with the organic acid production against skin pathogens. At the same time, most of them inhibit biofilm formation, but only the probiotic called as Propioniferax innocua can break down the mature biofilm (12). These properties are important for the effectiveness of probiotics in the prevention and treatment, since eczema is a hereditary skin disease.

\section{The Importance of Eczema in Allergic Disease Development}

The overall prevalence of allergic diseases in the world is $20 \%$ on average. The prevalence of $A D$ in developed northern European countries and the United States is also approximately $20 \%$ (13). Because AD and childhood eczema are the first signs (the first step of atopic/allergic walking (march) of the susceptibility to allergic diseases, it is the best way to study on eczema if probiotics should be evaluated for the prevention and treatment of allergic diseases. Therefore, the first studies in the literature were carried out by researchers on this disease (14).

\section{The role of probiotics in the prevention of eczema}

Studies conducted on eczema in the literature were started by Majamaa and Isolauri (14) right before 2000s. Because the methods used in the studies that were performed for the last 20 years were not standardized, probiotics were sometimes given to the mother in the prenatal period (pregnancy) or to the mother in the postnatal period if they were breastfeeding, or to the baby if the mother was not breastfeeding, or to the mother and/or baby in both the prenatal and postnatal periods (15-17).
One of the first important studies is the RCT that was reported in 2001 by Kalliomaki et al. (18) Lactobacillus rhamnosus GG (LGG) was given to 145 Finnish pregnant and breastfeeding mothers, or to the child if not breastfed, to examine the incidence of atopic eczema for up to 2 years, and it was demonstrated that the development of eczema decreased in risky infants by half (from $46 \%$ to $23 \%$ ). The same group of authors continued to follow-up the patients and showed that the probiotic effect lasted up to 4 years. At 4 years of age, eczema developed in 14 out of 53 (RR: 0.57) of those who had atopic eczema and continued to receive LGG, and in 25 out of 54 of Finnish children receiving placebo (19). However, in the study conducted in German children by Kopp et al. in 2008 with the same method and the same probiotic LGG, there was no difference in the AD frequency at 2 years of age. In comparison to the control group, there was no difference in terms of clinical or immunological effects (20). In another study conducted by Huurre et al. in Finnish individuals, a different probiotic mixture (LGG+Bifidobacterium) with the same method (pre- and postnatal) was used, and no effect was observed in those who participated in the study conducted at 1 year of age (21). These studies indicate that the same probiotics cause different effects or are ineffective in the same race and that different probiotics do not lead to the same outcome in the same race.

\section{The importance of the time to give probiotics: Prenatal or postnatal?}

The data related to prenatal and postnatal administration and their results are summarized in Table 1 and discussed in the following section.

\section{Only prenatal probiotic supplement}

Although the use of prenatal/antenatal (during pregnancy) probiotics was applied frequently, it was abandoned because of the lack of efficacy in postnatal studies. The only RCT we found in the PubMed scan was the one conducted by Boyle et al. (22) In this study, as of the $36^{\text {th }}$ gestational week, LGG was administered at a dose of $1.8 \times 10 \mathrm{cfu} /$ day (10) in 250 pregnant women who would deliver risky babies. Prenatal probiotic administration did not reduce the development risk of eczema or IgE-associated eczema (22).

\section{Prenatal and postnatal supplement (prenatal mother and postnatal breastfeeding mother and/or infant)}

A longer duration of direct administration in prenatal mothers and postnatal breastfeeding mothers or infants was found to be effective in the prevention of atopic (IgE-associated eczema) and nonatopic eczema in at least six out of nine RCTs. In two RCTs of Wickens and in three RCTs of Kalliomaki, probiotics were given to mothers in the prenatal period and to breastfeeding mothers and infants in the postnatal period. In two studies reported by Rautava et al. in 2002 and 2012, probiotics were given to a prenatal mother and a postnatal breastfeeding mother. Of the studies in which probiotics were given to prenatal mothers and infants, two belong to Allen et al., one belongs to Kuitunen et al., and two belong to Kukkonen et al. (15-17). The reason why this administration method became successful only due to prenatal or postnatal administration was attributed to the modification of the maternal vaginal flora and the intestinal flora of the infant with the effect of probiotics. In addition to the postnatal administration, probi- 
Table 1. The effects of probiotics on disease in terms of the time of administration, according to the sample studies to prevent atopic dermatitis

\begin{tabular}{|c|c|c|c|c|}
\hline Time of Administration & Probiotic Types & Result & Dose & Source \\
\hline Prenatal (to mother) & LGG & $\leftrightarrow$ & $\geq 109-10$ & 22 \\
\hline \multirow[t]{3}{*}{ Prenatal+Postnatal (to mother) } & LGG, Bifidobacterium lactis Bb12 & $\leftrightarrow$ & $\geq 109-10$ & 21 \\
\hline & LGG, Bifidobacterium Bb-12, Lactobacillus acidophilus La-5 & $\downarrow$ & $\geq 109-10$ & 36 \\
\hline & $\begin{array}{l}\text { Lactobacillus rhamnosus LP+Bifidobacterium longum or } \\
\text { Lactobacillum paracasei+ Bifidobacterium longum }\end{array}$ & $\downarrow, \downarrow$ & $\geq 109-10$ & $15-17,73$ \\
\hline \multirow[t]{7}{*}{ Prenatal+Postnatal (to mother+infant) } & LGG & $\downarrow$ & $\geq 109-10$ & $18,19,45$ \\
\hline & Lactobacillus rhamnosus HN001, Bifidobacterium & & & \\
\hline & lactis HN019 & $\downarrow$ & $\geq 109-10$ & $32,33,46$ \\
\hline & Lactobacillus reuteri & $\leftrightarrow$ & $\geq 109-10$ & 38,47 \\
\hline & $\begin{array}{l}\text { LGG, Lactobacillus rhamnosus LC705, Bifidobacterium } \\
\text { breve Bb99, Propionibacterium shermanii }\end{array}$ & $\downarrow$ & $\geq 109-10$ & 41 \\
\hline & LGG & $\leftrightarrow$ & $\geq 109-10$ & 20 \\
\hline & $\begin{array}{l}\text { Bifidobacterium bifidum, Bifidobacterium lactis, } \\
\text { Lactobacillus acidophilus }\end{array}$ & $\downarrow$ & $\geq 109-10$ & 31 \\
\hline Prenatal+Postnatal (to infant) & Bifidobacterium bifidum, Bifidobacterium lactis, Lactococcus lactis & $\downarrow$ & $\geq 109-10$ & 30 \\
\hline \multirow[t]{4}{*}{ Postnatal (to infant) } & Lactobacillus acidophilus & $\leftrightarrow, \uparrow *$ & $\geq 109-10$ & 23 \\
\hline & Lactobacillus F19 & $\downarrow, \leftrightarrow * *$ & $\geq 109-10$ & 28,48 \\
\hline & Lactobacillus acidophilus & $\leftrightarrow, \uparrow *$ & $\geq 109-10$ & 49 \\
\hline & Escherichia coli & $\downarrow, \downarrow * * *$ & $\geq 109-10$ & 26 \\
\hline Postnatal (to mother) & Lactobacillus casei & $\leftrightarrow$ & $\geq 109-10$ & 24 \\
\hline
\end{tabular}

otic supplement to prenatal mothers shows that it can be effective in preventing allergy development by providing the rapid colonization of the infant's intestines and by causing changes in the breast milk content. Systematic reviews and meta-analysis studies have demonstrated the superiority of this administration method (15-17).

\section{Only postnatal probiotic supplement (to mother or infant)}

Most studies were performed with postnatal probiotic supplementation, and they were found to be ineffective. In the RCT reported by Taylor et al. in 2007, it was found that probiotic administration in the first 6 months in a high-risk baby did not reduce the AD risk, but it increased allergen sensitization (23). There is a study of Ortiz-Andrellucchi et al. (24) with a postnatal breastfeeding mother. So, far, we have found no studies in which probiotics were administered in both a postnatal breastfeeding mother and an infant. Studies in which probiotics were given to infants postnatally were conducted by Hascoet et al. (25), Lodinova et al. (26), Morisset et al. (27), and West et al. (28). Only in the study by Lodinova et al. in which they used E.coli as a probiotic, an effect was seen even in long term (26).

Failure in this way may be attributed to the fact that the intestinal colonization of the baby cannot be affected through the vaginal flora, and the immune system of an infant between the first 3 to 6 months does not grow mature enough to be modified (29).

\section{The role of the probiotic type: Bifidobacteria or Lactobacilli?}

In two studies involving a Bifidobacteria-weighted probiotic mixture, the expected effect was seen in the high-risk group $(30,31)$. It was reported in a study that Lactobacillus rhamnosus was more successful in reducing eczema, and Bifidobacteria species such as Bifidobacterium animalissubsp. lactis had no effect when used alone (32). Bifidobacteria have often been used in combination with other probiotics.

Lactobacillus rhamnosus $\mathrm{GG}$ has been found to be effective in preventing the $A D$ development in the long term. Similarly, the efficacy of Lactobacillus rhamnosus HN001 has been shown to prevent the development of $A D$ up to 6 years of age in children at high risk. The fact that the same effect was not seen with Bifidobacterium lactis HN019 suggests that the effect depends on the type (33). In meta-analysis studies, Lactobacillus-containing probiotics have been shown to be superior to Bifidobacteria (34). In particular, when the prenatal and postnatal use of LGG is compared with placebo versus only prenatal use (risk ratio: 0.88 vs. 0.68 ), the effect between 12 and 24 months is very apparent (35).

\section{The role of probiotic mixtures}

In a study conducted in Norway, the probiotic mixture (LGG, Lactobacillus acidophilus La-5, and Bifidobacterium animalis) was given to the mother for 1 month in the prenatal period and to the breastfeeding mother for 3 months in the postnatal period; it was 
observed that atopic eczema and eczema decreased at 2 years of age (OR: 0.51) (36).

In the study in which a probiotic mixture (two Lactobacilli, Bifidobacteria, and Propionibacterium) was used in a high-risk group, the incidence of IgE-associated allergic disease was found low in the subgroup in which only cesarean births were evaluated at the age of 5 years (37).

In a study conducted by Huurre et al. in Finnish children, pre-/postnatal LGG and Bifidobacterium probiotic mixtures were used and evaluated at 1 year of age; however, it was not found effective (21).

It has been shown in meta-analysis studies that probiotic mixtures containing Lactobacillus are superior to others (16).

\section{The role of eczema type (IgE-associated (atopic) eczema/non-atopic eczema)}

In more than five trials, it was found to be effective in atopic (IgErelated, especially with nutritional allergy) eczema or atopic eczema/dermatitis (38-42). Although not very clearly, this effect has been partially shown in meta-analyses $(43,44)$.

\section{Studies based on a long-term follow-up in terms of preventing $A D$}

Kalliomaki et al. (45) have shown that its protective effect against eczema (OR: 0.58 ) continues in a period ranging from 4 to 7 years in the group receiving $L G G$.

Wickens et al. (46) have shown the efficacy of Lactobacillus rhamnosus HN001 in the prevention of the AD development by 6 years of age in high-risk children. The same effect was not seen with Bifidobacterium lactis HN019, suggesting that the effect depends on the type of probiotic.

In the study by Abrahamsson et al. (47), Lactobacillus reuteri was used in children from 232 families with allergic diseases in Sweden in the last month of pregnancy and within the first year after birth, and 184 children were able to complete the 7-year follow-up. The prevalence of $\mathrm{AD}$ was not found to be any different in comparison with the control group (47). Similarly, it was found in a study conducted by West et al. that Lactobacillus paracasei (LF19) did not have any effect on allergic diseases in Swedish children who were followed up until 8 to 9 years of age (48).

There are studies investigating the long-term effects of probiotics. It was seen that there was no probiotic effect in the evaluations made after 1-year follow-up of Taylor et al. (23) and 2.5-year follow-up period of Prescott et al. (49). In the study by Kukkonen et al., the probiotic was found to be effective for 2 years (41). In the study by Kuitunen et al., it was found to be effective only in those who were born by cesarean section after the follow-up for 5 years (37). In the study by Lin and Loo et al., the probiotic given within the first postnatal 6 months was not found to be effective in the 5 th year in a risky Asian infant $(50,51)$. Simpson et al. (52) reported that the probiotics given in the perinatal (maternal) period were effective for 6 years. The probiotic $E$. Coli that was given in the postnatal period was found to be effective even when examined 10 and 20 years later (53).
According to the meta-analysis by Zuccotti et al., the effects of probiotics are more apparent in the first 2 years of age, and this effect decreases over time in older ages (16).

\section{The Role of Probiotics in the Treatment of Eczema}

According to the data in the literature, it has been reported that the effect of a probiotic supplement generally leads to a decrease in the eczema scoring SCORAD and in the symptoms of the patients, as well as an increase in the quality of life. In most studies, a decrease in SCORAD and an increase in the quality of life have been shown to continue for 4 weeks after probiotic discontinuation (54). In some studies, topical probiotic application as a gel complex containing Lactobacillus salivarius LS01 at high concentration has also been shown to benefit $A D$ patients (55).

\section{Probiotics leading to significant improvement}

Lactobacillus acidophilus L-92 has been found to be effective in a large number of studies investigating its role in treatment $(56,57)$.

\section{Probiotics leading to partial improvement}

In studies using probiotics such as Lactobacillus plantarum CJLP133 and Lactobacillus salivarius, a partial improvement in SCORAD and in the quality of life has been reported (58).

\section{Probiotics that are ineffective}

Probiotics containing Lactobacillus paracasei or Bifidobacterium lactis have been found to be ineffective in the studies conducted by Gore et al. (59) and several other authors, and in the reviews reported by Torley et al. (60).

A meta-analysis related to the treatment was published by Kim et al. It has been emphasized that it may be useful in the treatment of moderate-severe eczema in children and adults (61).

\section{Compilations/Meta-analyses Discussing the Role of Probiotics in the Prevention/Treatment of Eczema}

In their meta-analyses, Van der Aa et al. (62) have reached the conclusion that probiotics are not involved in the prevention/treatment of AD in children. As Eigenmann et al. (63) concluded, it was found that the efficacy generally occurred with the continuation of the combined use of probiotics in early infancy, which was started during pregnancy. As Kuitunen et al. (64) and the others noted, the most obvious effect was found specific to Lactobacillus rhamnosus supplementation in mothers during the prenatal period and directly in babies during the postnatal period (65). It is reported in the meta-analysis by Lee et al. (66) that it is effective in the prevention rather than in the treatment, and also it is reported in Baquerizo et al. (67) that it can also reduce the incidence of eczema (66, 67). In conclusion, in reviews and meta-analyses investigating the role of probiotics in the prevention and treatment of $A D$, it has been shown that probiotics are more effective in the prevention than in the treatment and can reduce the incidence of eczema.

In the Cochrane meta-analysis that was reported in 2007, a total of 1477 infants were evaluated in five out of 12 RCTs through meta-analysis. It was found that eczema decreased (RR: 0.82) and Lactobacillus rhamnosus was beneficial in the high-risk group (68). In the Cochrane meta-analysis that was reported in 2008 , probiot- 


\begin{tabular}{|c|c|c|c|c|c|}
\hline Disease & Probiotics & Timing & Dose & Result & Reference \\
\hline \multicolumn{6}{|l|}{ Atopic Dermatitis } \\
\hline Prevention & LGG & Prenatal+Postnatal & $\geq 109-10$ & $\downarrow$ & $18-20,45$ \\
\hline Treatment & LGG & Childhood & $\geq 109-10$ & $\downarrow$ & 61 \\
\hline \multicolumn{6}{|l|}{ Nutritional Allergy } \\
\hline Prevention & Various & Prenatal+Postnatal & $\geq 109-10$ & $\leftrightarrow$ & $68,72,78$ \\
\hline Treatment & LGG & Infancy & $\geq 109-10$ & $\downarrow$ & $14,74,75$ \\
\hline \multicolumn{6}{|l|}{ Allergic Rhinitis } \\
\hline Prevention & Various & Prenatal+Postnatal & $\geq 109-10$ & $\leftrightarrow$ & $18-20,45$ \\
\hline Treatment & Bifidobacterium & Early childhood & $\geq 109-10$ & $\downarrow$ & 79,80 \\
\hline \multicolumn{6}{|l|}{ Asthma } \\
\hline Prevention & Various & Prenatal+Postnatal & $\geq 109-10$ & $\leftrightarrow$ & $18-20,45$ \\
\hline Treatment & Lactobacillus & Game child & $\geq 109-10$ & $\leftrightarrow$ & 83,84 \\
\hline
\end{tabular}

ics were not proven to be effective in the eczema treatment (69). In the Cochrane meta-analysis that was reported in 2009, RR was found as 0.82 for eczema, and as 0.80 for atopic eczema (70). Although it is mentioned in the Cochrane meta-analyses that probiotics have a positive effect, it has been emphasized that a definite conclusion cannot be reached in this respect.

As in the World Allergy Organization (WAO) guideline that was reported in 2012 and that investigated the clinical use of probiotics in childhood allergy, it was specified that they have no effect in the prevention and treatment in some international guidelines (WAO and European Association of Allergies and Clinical Immunology (EAACI)) (71). It is also mentioned in the 2014 guidelines by the EAACl that they have no effect in the prevention (72). In a 2015 WAO guidelines for the prevention of allergic diseases (WAO-GLAD-P), it was emphasized that probiotics could be used in pregnancy, in the mother and child if the risk of disease development is high (73).

\section{The Use of Probiotics in 0ther Allergic Diseases}

Here, nutrient allergies, allergic rhinitis, asthma, and the effects on refractory chronic urticaria will be discussed (Table 2).

\section{Nutritional Allergy}

Studies on the prevention and treatment of food allergy are not as common and numerous as those on AD. It was seen in the first publications that SCORAD decreased with the probiotic effect in eczematous patients with cow's milk allergy $(14,39,42)$. In patients with cow's milk allergy, probiotic (LGG) supplements, as in baby food, have been shown to cause a tolerance induction in these patients $(14,74)$. In a study conducted by Tang et al. (75), it was demonstrated that the probiotic that was added to oral immunotherapy (PPOIT study) in patients with peanut allergy was useful in the development of tolerance.

In some meta-analyses of the studies on food allergy, it was shown that food tolerance, sensitization, and SCORAD were not affected (76). In the meta-analysis of the studies on nutritional allergy,
Zhang has shown that the prenatal (mother) and postnatal (infant) probiotics reduce the risk of atopy and food hypersensitivity (RR: 0.78 and 0.77 , respectively) (77).

In a Cochrane meta-analysis in 2007, it was noted that probiotics have no protective effect on food allergies (68). In the evaluation by Kong et al., prenatal and postnatal probiotic supplements were found to have a protective effect on food allergies (RR: 0.88) (78). In the 2014 guidelines by EAACI, it is mentioned that probiotics do not have any effects on food allergy (72).

\section{The Role of Probiotics on Allergic Rhinitis}

\section{Seasonal and perennial allergic rhinitis}

In addition to those who state that probiotics are ineffective in the treatment of seasonal and persistent allergic rhinitis, there are also researchers who state that probiotics are effective. Lactobacillus species (L. casei, L. acidophilus strain L-92, L. paracasei-33) were found to be useful before and after the season $(79,80)$. In a study with probiotic-impregnated bed quilt/ pillow cases, an improvement was found in the symptoms of the patients with allergic rhinitis, and the quality of life increased (81).

\section{Allergic rhinitis: Meta-analysis}

In 2015, an evaluation was made of 23 studies, and 1919 patients in the compilation of Zajac et al. (82), which included one of the few meta-analyses about allergic rhinitis. Despite the improvement in the symptoms and the quality of life of patients with allergic rhinitis, the available data are limited, and more qualified studies are needed.

\section{The Role of Probiotics in Asthma}

\section{Prevention of asthma development}

It was shown in some studies that probiotics do not have any effects $(20,23,38)$. Similarly, Kalliomaki et al. (45) and Kuitunen et al. $(37,64)$ found that they were not effective over the age group of $5-8$ years. On the contrary, Johansson and Van der Aa et al. $(62,70)$ showed that they were effective at 5 years of age. 


\section{Asthma treatment}

In addition to those who report that probiotics are ineffective in the treatment of asthma, some say they are effective $(83,84)$.

\section{Allergic Airway (Allergic Rhinitis and Asthma) Disease}

Studies on asthma and allergic rhinitis are very limited in the literature, and some of them examined allergic airway disease (allergic rhinitis+asthma), and results were tried to be achieved. The RCT, compilation, and meta-analyses will be respectively presented below.

\section{Studies for Prevention}

A 7-year follow-up revealed no effect of probiotics on respiratory allergy and allergic airway disease (AR and asthma) (85). Probiotics containing LGG were found to have no effect on airway symptoms at the age of 4 years (86).

Compilations of studies on the treatment of allergic airway disease Although an increase in the quality of life was reported in the evaluations made with the compilations, it was seen that laboratory parameters were not affected (87).

If we summarize these studies, (a) probiotics were used in different strains, doses, and durations. A minimal dose was $>5 \times 109 \mathrm{cfu} /$ day, and a minimal duration of use was 1 month. b) Lactobacillus (acidophilus, rhamnosus, casel) strains were used in asthmatic patients, and Bifidobacterium (longum) along with them was used in allergic rhinitis. c) Its benefit is more apparent in allergic rhinitis than in asthma, but it may be due to the dose of Lactobacillus.

Meta-analyses of the studies conducted on allergic airway disease In the meta-analyses by Vliagoftis et al. (88), in nine out of 12 RCTs, the symptom score and drug use decreased in perennial allergic rhinitis. There was no effect on asthma (88). In the meta-analysis in which Das et al. evaluated 12 studies, despite the fact that probiotics significantly increased the quality of life in allergic rhinitis, they were not found to be beneficial in asthma. However, probiotics were found effective in reducing the attacks of asthma and allergic rhinitis (87). In a compilation by Zajak et al. (82), it was reported that probiotics could be useful in alleviating symptoms of allergic airway disease and improving the quality of life. Although they had no effect in the prevention of allergic rhinitis according to the meta-analysis of Peng et al. (89), it was stated that they provided an improvement in the quality of life and nasal symptom scores.

In general, probiotics have been shown to be effective in the treatment of allergic rhinitis, but ineffective in prevention. It is accepted that they do not have any effects in the prevention and treatment of asthma.

\section{Refractory Chronic Spontaneous Urticaria}

In a study that Nettis et al. (90) conducted on 52 patients (aged 1972 ), it was found that probiotics could be beneficial in some patients.

\section{Causes of Conflicting Results in Probiotic Studies}

Methodological reasons leading to conflicting results in similar studies with probiotics can be summarized as follows (4, 5, 7, 8): i) the difference in the race and the family of the host that participated in the study, ii) the selection of participants using a non-selected cohort against those with high risk, iii) the allergic condition of the host (the severity of eczema, the presence of probiotic (pre- or postnatal), v) the length of the intervention, vi) the selection of optimal bacterial strain (the selection of countryspecific strains (91)), vii) the dose of probiotics, viii) the way and means of the administration of probiotics, ix) whether or not there is any accompanying use of prebiotics, $\mathrm{x}$ ) hygienic conditions of the working environment, and xi) the use of the data repository for the evaluation of different study outcomes $(35,92)$.

\section{Conclusion}

If a probiotic is to be used to prevent $A D$ in particular, it should be applied in the prenatal period (to the pregnant woman) and then in the postnatal period (to the breastfeeding mother, and to baby if not being breastfed). At the same time, this is the easiest application. Only prenatal or postnatal use was found to be unsuccessful in comparison to the combined use in both periods $(22,64$, 93). When given to mother, the intestinal microflora modification occurs in the infant who is born through the vaginal flora. In addition to probiotics, immunoregulatory factors such as TGF- $\beta$ and IgA in the mother's milk pass to the baby through breastfeeding (94). In this way, probiotics may be effective in the prevention of eczema, but they have no effect in the prevention of other allergic diseases. It is known that the duration of prevention may last for 7-10 years, but it is not known to what extent it affects the incidence of the disease for the entire lifetime (45-53). Even if probiotics are not useful in the prevention, they may be useful in the treatment of eczema and respiratory allergic diseases (95).

\section{Side Effects and Situations that Require Caution}

Lactobacilli, lactococci, bifidobacterial, and fungi are "generally recognized as safe: GRS“ by the WHO $(4,5,7)$. However, bacteremia and sepsis have been reported after the use of probiotics in the gastrointestinal (short bowel, etc.) and immunocompromized patients (96). No sepsis has been reported with Bifidobacteria. Fungemia was seen with S.boulardii in catheter/nasogastric tube users (97). Endocarditis and liver abscess have been reported in Lactobacilli users (98). Intestinal ischemia, the GIS side effects such

\begin{tabular}{|lc|}
$\begin{array}{l}\text { Table 3. Considerations for the use of probiotics that are } \\
\text { generally recognized as safe }\end{array}$ & Source \\
\hline Situation & 96 \\
\hline Premature baby & 96 \\
\hline Person with immunodeficiency or immunosuppression & 96 \\
\hline Sepsis development & 97 \\
\hline Fungemia development & 98 \\
\hline Endocarditis development & 98 \\
\hline Liver abscess development & 23,103 \\
\hline Risk of autoimmune disease & 23,103 \\
\hline Risk of allergic disease & 102 \\
\hline Containing a protein from cows milk and eggs & 104 \\
\hline Increasing antibiotic resistance & 105 \\
\hline Decreasing the response to vaccination & 107 \\
\hline Risk of contamination & 107 \\
\hline Preparation with low dose and quality & 99 \\
\hline D-lactic acidosis &
\end{tabular}


as diarrhea (heat-inactivated LGG supplementation), D-lactic acidosis, eosinophilic syndrome (vasculitis+mononeuritis multiplex), and cholecystitis with Lactobacillus fermentum have been reported (69, 99-101).

Caution is required when used in premature infants, and in patients with immunodeficiency, immunocompromized, and autoimmune diseases $(4,5,7)$ (Table 3$)$. Care should be paid in persons with an allergy to cows milk and eggs due to the content of probiotic preparations (102). The risks of autoimmune disease or the risk of increasing the incidence of allergic diseases such as in asthma (sensitization, recurrent wheezing), as shown in some studies, should also be kept in mind $(23,103)$. It is also mentioned that it can reduce the antibiotic resistance (tetracycline, etc.) with gene transfer to other microorganisms in the environment (104). When used with vaccination at the same time, a decrease in vaccine response was detected (105).

Even baby food sold commercially on the market contains three types of probiotics (Bifidobacterium lactis, Bifidobacterium infantis, and LGG) and/or prebiotics. In 2011, ESPGHAN did not suggest the routine use of baby food containing probiotics and/or prebiotics, but it found it safe in terms of side effects and growth (106). Products sold commercially such as some commercial vitamin supplements, yogurt, which is sold as a food along with oral rehydration liquid, and kefir contain probiotics. It is a matter of debate how much of the content of these food products contains the necessary dose and the appropriate probiotics. In studies conducted by ESPGHAN concerning the content of commercial preparations on the market, it was revealed that the strains that were mentioned could not be found in the content, and some preparations were even contaminated with other microorganisms (107).

\section{Near-Future Expectations}

It is unclear whether the inhibitory/preventive effect on allergic diseases is a fact or not and whether it reduces the true incidence of allergic disease. It has not yet been elucidated how long it takes to prevent the development of allergic diseases in the long term. In our opinion, it seems to delay the onset of allergic diseases $(4,5,7)$.

Nowadays, probiotics are designed according to the function to be executed before being administered to the body (designer probiotics). When given to the body, they can serve as vectors that provide the mucosal access of therapeutic protein and DNA vaccines. For example, they deliver recombinant Lactococcus DNA to eukaryotic cells. Lactobacillus lactis delivers the plasmid to the epithelial membrane cells (108). The combination of LAB used as an adjuvant or Clostridium butyricum with the major birch pollen allergen (Bet $\checkmark 1$ ) has been used successfully in the immunotherapy of pollen or in the immunotherapy against mites $(109,110,111)$. Recombinant LAB containing Lactococci and Lactobacilli could be produced as strains of probiotic bacteria (IL-10 releasing Lactobacillus lactis) expressing the Th1 cytokine (IL-10/-12) (112). Similarly, produced probiotic bacteria expressing food antigen ( $\beta$-lactoglobulin (milk) and ovalbumin (egg)) were started to be tried against foods in immunotherapy $(113,114)$.

Peer-review: Externally peer-reviewed.

Conflict of Interest: The author has no conflict of interest to declare.
Financial Disclosure: The author declared that this study has received no financial support.

\section{References}

1. Sharma M, Shukla G. Metabiotics: One step ahead of probiotics; an insight into mechanisms involved in anticancerous effect in colorectal cancer. Front Microbiol 2016; 7: 1940. [CrossRef]

2. Chua KJ, Kwok WC, Aggarwal N, Sun T, Chang MW. Designer probiotics for the prevention and treatment of human diseases. Curr Opin Chem Biol 2017; 40: 8-16. [CrossRef]

3. Food and Agriculture Organization, World Health Organization (FAO/ WHO) Report of Joint FAO/WHO expert consultation on evaluation of health and nutritional properties of probiotics in food including powder milk with live lactic acid bacteria. FAO/WHO Report no. 10-1-2001. WHO INT; Córdoba, Argentina.

4. Özdemir Ö. Prebiyotikler, probiyotikler ve alerji (Bölüm 76). Şekerel $\mathrm{BE}$, editor. Çocukluk Çağında Allerji, Astım ve İmmünoloji. Balıkesir: Ada Basın-Yayın; 2015; 819-43.

5. Ozdemir 0 . Various effects of different probiotic strains in allergic disorders: an update from laboratory and clinical data. Clin Exp Immunol 2010; 160: 295-304. [CrossRef]

6. Sudo N, Sawamura S, Tanaka K, Aiba Y, Kubo C, Koga Y. The requirement of intestinal bacterial flora for the development of an IgE production system fully susceptible to oral tolerance induction. J Immunol 1997; 159: 1739-45.

7. Ozdemir 0. Prebiotics and probiotics in allergy: Potential mechanisms of prebiotics' and probiotics' actions in allergy - (Part 1). MOJ Immunol 2016; 3: 00069. [CrossRef]

8. Özdemir Ö. Mechanisms of preventative and therapeutic role of probiotics in different allergic and autoimmune disorders. Open Journal of Immunology 2013; 3: 1-16. [CrossRef]

9. Dev S, Mizuguchi H, Das AK, Matsushita C, Maeyama K, Umehara H, et al. Suppression of histamine signaling by probiotic Lac-B: a possible mechanism of its anti-allergic effect. J Pharmacol Sci 2008; 107: 15966. [CrossRef]

10. Morgan AR, Han DY, Wickens K, Barthow C, Mitchell EA, Stanley TV, et al. Differential modification of genetic susceptibility to childhood eczema by two probiotics. Clin Exp Allergy 2014; 44: 1255-65. [CrossRef]

11. Lew LC, Liong MT. Bioactives from probiotics for dermal health: functions and benefits. J Appl Microbiol 2013; 114: 1241-53. [CrossRef]

12. Lopes EG, Moreira DA, Gullón P, Gullón B, Cardelle-Cobas A, Tavaria FK. Topical application of probiotics in skin: adhesion, antimicrobial and antibiofilm in vitro assays. J Appl Microbiol 2013; 114: 1241-53.

13. Nutten S. Atopic Dermatitis: Global Epidemiology and Risk Factors. Ann Nutr Metab 2015; 66: 8-16. [CrossRef]

14. Majamaa H, Isolauri E. Probiotics: a novel approach in the management of food allergy. J Allergy Clin Immunol 1997; 99: 179-85. [CrossRef]

15. Cuello-Garcia CA, Brożek JL, Fiocchi A, Pawankar R, Yepes-Nu-ez JJ, Terracciano $L$, et al. Probiotics for the prevention of allergy: A systematic review and meta-analysis of randomized controlled trials. J Allergy Clin Immunol 2015; 136: 952-61. [CrossRef]

16. Zuccotti G, Meneghin F, Aceti A, Barone G, Callegari ML, Di Mauro A, et al. Probiotics for prevention of atopic diseases in infants: systematic review and meta-analysis. Allergy 2015; 70: 1356-71. [CrossRef]

17. Ricci G, Cipriani F, Cuello-Garcia CA, Brożek JL, Fiocchi A, Pawankar $R$, et al. A clinical reading on "World Allergy Organization-McMaster University Guidelines for Allergic Disease Prevention (GLAD-P): Probiotics". World Allergy Organ J 2016; 9: 9. [CrossRef]

18. Kalliomäki M, Salminen S, Arvilommi H, Kero P, Koskinen P, Isolauri E. Probiotics in primary prevention of atopic disease: a randomised placebo-controlled trial. Lancet 2001; 357: 1076-9. [CrossRef]

19. Kalliomäki M, Salminen S, Poussa T, Arvilommi H, Isolauri E. Probiotics and prevention of atopic disease: 4-year follow-up of a randomised placebo-controlled trial. Lancet 2003; 361: 1869-71. [CrossRef] 
20. Kopp MV, Hennemuth I, Heinzmann A, Urbanek R. Randomized, double-blind, placebo-controlled trial of probiotics for primary prevention: no clinical effects of Lactobacillus GG supplementation. Pediatrics 2008; 121: 850-6. [CrossRef]

21. Huurre A, Laitinen K, Rautava S, Korkeamäki M, Isolauri E. Impact of maternal atopy and probiotic supplementation during pregnancy on infant sensitization: a double-blind placebo-controlled study. Clin Exp Allergy 2008; 38: 1342-8. [CrossRef]

22. Boyle RJ, Ismail IH, Kivivuori S, Licciardi PV, Robins-Browne RM, Mah LJ, et al. Lactobacillus GG treatment during pregnancy for the prevention of eczema: a randomized controlled trial. Allergy 2011; 66: 509-16. [CrossRef]

23. Taylor AL, Dunstan JA, Prescott SL. Probiotic supplementation for the first 6 months of life fails to reduce the risk of atopic dermatitis and increases the risk of allergen sensitization in high-risk children: a randomized controlled trial. J Allergy Clin Immunol 2007; 119: 184-91. [CrossRef]

24. Ortiz-Andrellucchi A, Sanchez-Villegas A, Rodriguez-Gallego C, Lemes A, Molero T, Soria A, et al. Immunomodulatory effects of the intake of fermented milk with Lactobacillus casei DN114001 in lactating mothers and their children. Br J Nutr 2008; 100: 834-45. [CrossRef]

25. Hascoet JM, Hubert C, Rochat F, Legagneur H, Gaga S, Emady-Azar S, et al. Effect of formula composition on the development of infant gut microbiota. J Pediatr Gastroenterol Nutr 2011; 52: 756-62. [CrossRef]

26. Lodinova-Zadnikova R, Prokesova L, Kocourkova I, Hrdy J, Zizka J. Prevention of allergy in infants of allergic mothers by probiotic Escherichia coli. Int Arch Allergy Immunol 2010; 153: 201-6.[CrossRef]

27. Morisset M, Aubert-Jacquin C, Soulaines P, Moneret-Vautrin DA, Dupont C. A non-hydrolyzed, fermented milk formula reduces digestive and respiratory events in infants at high risk of allergy. Eur J Clin Nutr 2011; 65: 175-83.[CrossRef]

28. West CE, Hammarstr€om ML, Hernell 0. Probiotics during weaning reduce the incidence of eczema. Pediatr Allergy Immunol 2009; 20 : 430-7. [CrossRef]

29. Damm JA, Smith B, Greisen G, Krogfelt KA, Clausen ML, Agner T. The influence of probiotics for preterm neonates on the incidence of atopic dermatitis-results from a historically controlled cohort study. Arch Dermatol Res 2017; 309: 259-64. [CrossRef]

30. Niers L, Martín R, Rijkers G, Sengers F, Timmerman H, van Uden N, et al. The effects of selected probiotic strains on the development of eczema (the PandA study). Allergy 2009; 64: 1349-58. [CrossRef]

31. Kim JY, Kwon JH, Ahn SH, Lee SI, Han YS, Choi YO, et al. Effect of probiotic mix (Bifidobacterium bifidum, Bifidobacterium lactis, Lactobacillus acidophilus) in the primary prevention of eczema: a doubleblind, randomized, placebo-controlled trial. Pediatr Allergy Immunol 2010; 21: 386-93. [CrossRef]

32. Wickens K, Black PN, Stanley TV, Mitchell E, Fitzharris P, Tannock GW, et al. A differential effect of 2 probiotics in the prevention of eczema and atopy: a double-blind, randomized, placebo controlled trial. J Allergy Clin Immunol 2008; 122: 788-94. [CrossRef]

33. Wickens K, Black P, Stanley TV, Mitchell E, Barthow C, Fitzharris P, et al. A protective effect of Lactobacillus rhamnosus HN001 against eczema in the first 2 years of life persists to age 4 years. Clin Exp Allergy 2012; 42: 1071-9. [CrossRef]

34. Yao TC, Chang CJ, Hsu YH, Huang JL. Probiotics for allergic diseases: realities and myths. Pediatr Allergy Immunol 2010; 21: 900-19. [CrossRef]

35. Szajewska H, Shamir R, Turck D, van Goudoever JB, Mihatsch WA, Fewtrell M. Recommendations on probiotics in allergy prevention should not be based on pooling data from different strains. J Allergy Clin Immunol 2015; 136: 1422. [CrossRef]

36. Dotterud CK, Storrø 0, Johnsen R, Oien T. Probiotics in pregnant women to prevent allergic disease: a randomized, double-blind trial. $\mathrm{Br}$ J Dermatol 2010; 163: 616-23. [CrossRef]

37. Kuitunen M, Kukkonen K, Juntunen-Backman K, Korpela R, Poussa T, Tuure T, et al. Probiotics prevent IgE-associated allergy until age 5 years in cesarean-delivered children but not in the total cohort. J
38. Abrahamsson TR, Jakobsson T, Böttcher MF, Fredrikson M, Jenmalm MC, Björkstén B, et al. Probiotics in prevention of IgE-associated eczema: a double-blind, randomized, placebo-controlled trial. J Allergy Clin Immunol 2007; 119: 1174-80. [CrossRef]

39. Viljanen M, Savilahti E, Haahtela T, Juntunen-Backman K, Korpela R, Poussa T, et al. Probiotics in treatment of atopic eczema/dermatitis syndrome in infants: a double-blind placebo-controlled trial. Allergy 2005; 60: 494-500. [CrossRef]

40. Sistek D, Kelly R, Wickens K, Stanley T, Fitzharris P, Crane J. Is the effect of probiotics on atopic dermatitis confined to food sensitized children? Clin Exp Allergy 2006; 36: 629-33. [CrossRef]

41. Kukkonen K, Savilahti E, Haahtela T, Juntunen-Backman K, Korpela $\mathrm{R}$, Poussa T, et al. Probiotics and prebiotic galacto-oligosaccharides in the prevention of allergic diseases: a randomized, double blind, placebo-controlled trial. J Allergy Clin Immunol 2007; 119: 192-8. [CrossRef]

42. Rosenfeldt V, Benfeldt E, Nielsen SD, Michaelsen KF, Jeppesen DL, Valerius $\mathrm{NH}$, et al. Effect of probiotic Lactobacillus strains in children with atopic dermatitis. J Allergy Clin Immunol 2003; 111: 389-95. [CrossRef]

43. Pelucchi C, Chatenoud L, Turati F, Galeone C, Moja L, Bach JF, et al. Probiotics supplementation during pregnancy or infancy for the prevention of atopic dermatitis: a meta-analysis. Epidemiology 2012; 23: 402-14. [CrossRef]

44. Kim HJ, Kim HY, Lee SY, Seo JH, Lee E, Hong SJ. Clinical efficacy and mechanism of probiotics in allergic diseases. Korean J Pediatr 2013; 56: 369-76. [CrossRef]

45. Kalliomäki M, Salminen S, Poussa T, Isolauri E. Probiotics during the first 7 years of life: a cumulative risk reduction of eczema in a randomized, placebo-controlled trial. J Allergy Clin Immunol 2007; 119: 1019-21. [CrossRef]

46. Wickens K, Stanley TV, Mitchell EA, Barthow C, Fitzharris P, Purdie G, et al. Early supplementation with Lactobacillus rhamnosus HN001 reduces eczema prevalence to 6 years: does it also reduce atopic sensitization? Clin Exp Allergy 2013; 43: 1048-57. [CrossRef]

47. Abrahamsson TR, Jakobsson T, Björkstén B, Oldaeus G, Jenmalm MC. No effect of probiotics on respiratory allergies: a seven-year follow-up of a randomized controlled trial in infancy. Pediatr Allergy Immunol 2013; 24: 556-61. [CrossRef]

48. West CE, Hammarström ML, Hernell O. Probiotics in primary prevention of allergic disease--follow-up at 8-9 years of age. Allergy 2013; 68: 1015-20. [CrossRef]

49. Prescott SL, Wiltschut J, Taylor A, Westcott L, Jung W, Currie H, et al. Early markers of allergic disease in a primary prevention study using probiotics: 2.5-year follow-up phase. Allergy 2008; 63: 1481-90. [CrossRef]

50. Lin JH. Supplementation with probiotics in the first 6 months of life did not protect against eczema and allergy in at-risk Asian infants: A 5-year follow-up. Pediatrics 2014; 134: 142. [CrossRef]

51. Loo EX, Llanora GV, Lu Q, Aw MM, Lee BW, Shek LP. Supplementation with probiotics in the first 6 months of life did not protect against eczema and allergy in at-risk Asian infants: a 5-year follow-up. Int Arch Allergy Immunol 2014; 163: 25-8. [CrossRef]

52. Simpson MR, Dotterud CK, Storrø O, Johnsen R, Øien T. Perinatal probiotic supplementation in the prevention of allergy related disease: 6 year follow up of a randomised controlled trial. BMC Dermatol 2015; 15: 13. [CrossRef]

53. Lodinová-Zádníková R, Cukrowska B, Tlaskalova-Hogenova H. Oral administration of probiotic Escherichia coli after birth reduces frequency of allergies and repeated infections later in life (after 10 and 20 years). Int Arch Allergy Immunol 2003; 131: 209-11. [CrossRef]

54. Michail SK, Stolfi A, Johnson T, Onady GM. Efficacy of probiotics in the treatment of pediatric atopic dermatitis: a metaanalysis of randomized controlled trials. Ann Allergy Asthma Immunol 2008; 101: 508-16. [CrossRef] 
55. Drago L, De Vecchi E, Toscano M, Vassena C, Altomare G, Pigatto P. Treatment of atopic dermatitis eczema with a high concentration of Lactobacillus salivarius LS01 associated with an innovative gelling complex: a pilot study on adults. J Clin Gastroenterol 2014; 48: 47-51. [CrossRef]

56. Yamamoto K, Yokoyama K, Matsukawa T, Kato S, Kato S, Yamada K, et al. Efficacy of prolonged ingestion of Lactobacillus acidophilus L-92 in adult patients with atopic dermatitis. J Dairy Sci 2016; 99: 5039-46. [CrossRef]

57. Torii S, Torii A, Itoh K, Urisu A, Terada A, Fujisawa T, et al. Effects of oral administration of Lactobacillus acidophilus L-92 on the symptoms and serum markers of atopic dermatitis in children. Int Arch Allergy Immunol 2011; 154: 236-45. [CrossRef]

58. Han Y, Kim B, Ban J, Lee J, Kim BJ, Choi BS, et al. A randomized trial of Lactobacillus plantarum CJLP133 for the treatment of atopic dermatitis. Pediatr Allergy Immunol 2012; 23: 667-73. [CrossRef]

59. Gore C, Custovic A, Tannock GW, Munro K, Kerry G, Johnson K, et al. Treatment and secondary prevention effects of the probiotics Lactobacillus paracasei or Bifidobacterium lactis on early infant eczema: randomized controlled trial with follow-up until age 3 years. Clin Exp Allergy 2012; 42: 112-22. [CrossRef]

60. Torley D, Futamura M, Williams HC, Thomas KS. What's new in atopic eczema? An analysis of systematic reviews published in 2010-11. Clin Exp Dermatol 2013; 38: 449-56. [CrossRef]

61. Kim SO, Ah YM, Yu YM, Choi KH, Shin WG, Lee JY. Effects of probiotics for the treatment of atopic dermatitis: a meta-analysis of randomized controlled trials. Ann Allergy Asthma Immunol 2014; 113: 217-26. [CrossRef]

62. Van der Aa LB, Heymans HS, van Aalderen WM, Sprikkelman AB. Probiotics and prebiotics in atopic dermatitis: review of the theoretical background and clinical evidence. Pediatr Allergy Immunol 2010; 21 : 355-67. [CrossRef]

63. Eigenmann PA. Evidence of preventive effect of probiotics and prebiotics for infantile eczema. Curr Opin Allergy Clin Immunol 2013; 13 : 426-31. [CrossRef]

64. Kuitunen M. Probiotics and prebiotics in preventing food allergy and eczema. Curr Opin Allergy Clin Immunol 2013; 13: 280-6. [CrossRef]

65. Mansfield JA, Bergin SW, Cooper JR, Olsen CH. Comparative probiotic strain efficacy in the prevention of eczema in infants and children: a systematic review and meta-analysis. Mil Med 2014; 179: 580-92. [CrossRef]

66. Lee J, Seto D, Bielory L. Meta-analysis of clinical trials of probiotics for prevention and treatment of pediatric atopic dermatitis. J Allergy Clin Immunol. 2008; 121: 116-121. [CrossRef]

67. Baquerizo Nole KL, Yim E, Keri JE. Probiotics and prebiotics in dermatology. J Am Acad Dermatol 2014; 71: 814-21. [CrossRef]

68. Osborn DA, Sinn JK. Probiotics in infants for prevention of allergic disease and food hypersensitivity. Cochrane Database Syst Rev 2007; 4: CD006475. [CrossRef]

69. Boyle RJ, Bath-Hextall FJ, Leonardi-Bee J, Murrell DF, Tang ML. Probiotics for treating eczema. Cochrane Database Syst Rev 2008; 4: CD006135. [CrossRef]

70. Johansson SG, Bieber T, Dahl R, Friedmann PS, Lanier BQ, Lockey RF, et al. J Allergy Clin Immunol 2004; 113: 832-6. [CrossRef]

71. WAO Special Committee on Food Allergy and Nutrition. Clinical Use of Probiotics in Pediatric Allergy (CUPPA): A World Allergy Organization Position Paper. World Allergy Organ J 2012; 5: 148-67. [CrossRef]

72. Muraro A, Halken S, Arshad SH, Beyer K, Dubois AE, Du Toit G, et al. EAACl food allergy and anaphylaxis guidelines. Primary prevention of food allergy. Allergy 2014; 69: 590-601. [CrossRef]

73. Fiocchi A, Pawankar R, Cuello-Garcia C. World Allergy Organization-McMaster University Guidelines for Allergic Disease Prevention (GLAD-P): Probiotics. World Allergy Organ J 2015; 8: 4. [CrossRef]

74. Berni Canani R, Nocerino R, Terrin G, Frediani T, Lucarelli S, Cosenza L, et al. Formula selection for management of children with cow's milk allergy influences the rate of acquisition of tolerance: a prospective multicenter study. J Pediatr 2013; 163: 771-7. [CrossRef]
75. Tang ML, Ponsonby AL, Orsini F, Tey D, Robinson M, Su EL, et al. Administration of a probiotic with peanut oral immunotherapy: A randomized trial. J Allergy Clin Immunol 2015; 135: 737-44. [CrossRef]

76. Toh ZQ, Anzela A, Tang ML, Licciardi PV. Probiotic therapy as a novel approach for allergic disease. Front Pharmacol 2012; 3: 171. [CrossRef]

77. Zhang GQ, Hu HJ, Liu CY, Zhang Q, Shakya S, Li ZY. Probiotics for Prevention of Atopy and Food Hypersensitivity in Early Childhood: A PRISMA-Compliant Systematic Review and Meta-Analysis of Randomized Controlled Trials. Medicine (Baltimore). 2016; 95: e2562. [CrossRef]

78. Kong XY, Yang Y, Guan J, Wang RZ. Probiotics' preventive effect on pediatric food allergy: a meta-analysis of randomized controlled trials. Chin Med Sci J 2014; 29: 144-7. [CrossRef]

79. Wang MF, Lin HC, Wang YY, Hsu CH. Treatment of perennial allergic rhinitis with lactic acid bacteria. Pediatr Allergy Immunol 2004; 15 : 152-8.[CrossRef]

80. Ivory K, Chambers SJ, Pin C, Prieto E, Arqués JL, Nicoletti C. Oral delivery of Lactobacillus casei Shirota modifies allergen-induced immune responses in allergic rhinitis. Clin Exp Allergy 2008; 38: 1282-9. [CrossRef]

81. Berings M, Jult A, Vermeulen H, De Ruyck N, Derycke L, Ucar H, et al. Probiotics-impregnated bedding covers for house dust mite allergic rhinitis: A pilot randomized clinical trial. Clin Exp Allergy 2017; 47: 1092-6. [CrossRef]

82. Zajac AE, Adams AS, Turner JH. A systematic review and meta-analysis of probiotics for the treatment of allergic rhinitis. Int Forum Allergy Rhinol 2015; 5: 524-32.[CrossRef]

83. Miraglia Del Giudice M, Maiello N, Decimo F, Fusco N, D' Agostino B, Sullo N, et al. Airways allergic inflammation and L. reuterii treatment in asthmatic children. J Biol Regul Homeost Agents 2012; 26: 35-40.

84. van de Pol MA, Lutter R, Smids BS, Weersink EJ, van der Zee JS. Synbiotics reduce allergen-induced T-helper 2 response and improve peak expiratory flow in allergic asthmatics. Allergy 2011; 66: 39-47. [CrossRef]

85. Matsui E. No effect of probiotics on respiratory allergies: A seven-year follow-up of a randomized controlled trial in infancy. Pediatrics 2014; 134: 141-2. [CrossRef]

86. Rose MA, Schubert R, Schulze J, Zielen S. Follow-up of probiotic Lactobacillus $\mathrm{GG}$ effects on allergic sensitization and asthma in infants at risk. Clin Exp Allergy 2011; 41: 1819-21. [CrossRef]

87. Das RR, Naik SS, Singh M. Probiotics as additives on therapy in allergic airway diseases: a systematic review of benefits and risks. Biomed Res Int 2013; 2013: 231979.[CrossRef]

88. Vliagoftis H, Kouranos VD, Betsi GI, Falagas ME. Probiotics for the treatment of allergic rhinitis and asthma: systematic review of randomized controlled trials. Ann Allergy Asthma Immunol 2008; 101: 570-9. [CrossRef]

89. Peng Y, Li A, Yu L, Qin G. The role of probiotics in prevention and treatment for patients with allergic rhinitis: A systematic review. Am J Rhinol Allergy 2015; 29: 292-8. [CrossRef]

90. Nettis E, Di Leo E, Pastore A, Distaso M, Zaza I, Vacca M, et al. Probiotics and refractory chronic spontaneous urticaria. Eur Ann Allergy Clin Immunol 2016; 48: 182-7.

91. Vernocchi P, Del Chierico F, Fiocchi AG, El Hachem M, Dallapiccola $\mathrm{B}$, Rossi $\mathrm{P}$, et al. Understanding probiotics' role in allergic children: the clue of gut microbiota profiling. Curr Opin Allergy Clin Immunol 2015; 15: 495-503. [CrossRef]

92. Elazab N, Mendy A, Gasana J, Vieira ER, Quizon A, Forno E. Probiotic administration in early life, atopy, and asthma: a meta-analysis of clinical trials. Pediatrics 2013; 132: 666-76. [CrossRef]

93. Özdemir Ö. The role of probiotics in atopic dermatitis prevention and therapy. In: Esparza-Gordillo J, Dekio I, Eds. Atopic Dermatitis - Disease Etiology and Clinical Management. InTech, Open Access Company, Croatia, 2012: 353-86. [CrossRef]

94. Munblit D, Boyle RJ. Modulating breast milk composition - the key to allergy prevention? Int Arch Allergy Immunol 2012; 159: 107-8. [CrossRef]

95. Özdemir Ö. Is there any effect of probiotics on allergic airway disease? J Chin Med Assoc 2015; 78: 627-8. [CrossRef] 
96. McClave SA, Heyland DK, Wischmeyer PE. Comment on: probiotic prophylaxis in predicted severe acute pancreatitis: a randomized, double-blind, placebo-controlled trial. JPEN J Parenter Enteral Nutr 2009; 33: 444-6. [CrossRef]

97. Roy U, Jessani LG, Rudramurthy SM, Gopalakrishnan R, Dutta S, Chakravarty $C$, et al. Seven cases of Saccharomyces fungaemia related to use of probiotics. Mycoses 2017; 60: 375-80. [CrossRef]

98. Kato K, Funabashi N, Takaoka H, Kohno H, Kishimoto T, Nakatani Y, et al. Lactobacillus paracasei endocarditis in a consumer of probiotics with advanced and severe bicuspid aortic valve stenosis complicated with diffuse left ventricular mid-layer fibrosis. Int J Cardiol 2016; 224 : 157-61. [CrossRef]

99. Munakata S, Arakawa C, Kohira R, Fujita Y, Fuchigami T, Mugishima H. A case of D-lactic acid encephalopathy associated with use of probiotics. Brain Dev 2010; 32: 691-4. [CrossRef]

100. Mendoza FA, Purohit S, Kenyon L, Jimenez SA. Severe eosinophilic syndrome associated with the use of probiotic supplements: a new entity? Case Rep Rheumatol 2012; 2012: 934324.

101. Chery J, Dvoskin D, Morato FP, Fahoum B. Lactobacillus fermentum, a pathogen in documented cholecystitis. Int J Surg Case Rep 2013; 4: 662-4. [CrossRef]

102. Martín-Munoz MF, Fortuni M, Caminoa M, Belver T, Quirce S, Caballero T. Anaphylactic reaction to probiotics. Cow's milk and hen's egg allergens in probiotic compounds. Pediatr Allergy Immunol 2012; 23 : 778-84. [CrossRef]

103. Peldan P, Kukkonen AK, Savilahti E, Kuitunen M. Perinatal probiotics decreased eczema up to 10 years of age, but at 5-10 years, allergic rhino-conjunctivitis was increased. Clin Exp Allergy 2017; 47: 975-9. [CrossRef]

104. Imperial IC, Ibana JA. Addressing the antibiotic resistance problem with probiotics: reducing the risk of its double-edged sword effect. Front Microbiol 2016; 7: 1983. [CrossRef]

105. Praharaj I, John SM, Bandyopadhyay R, Kang G. Probiotics, antibiotics and the immune responses to vaccines. Philos Trans R Soc Lond B Biol Sci 2015; 370. [CrossRef]

106. Braegger C, Chmielewska A, Decsi T, Kolacek S, Mihatsch W, Moreno $L$, et al. Supplementation of infant formula with probiotics and/or prebiotics: a systematic review and comment by the ESPGHAN com- mittee on nutrition. J Pediatr Gastroenterol Nutr 2011; 52: 238-50. [CrossRef]

107. Kolaček S, Hojsak I, Canani RB, Guarino A, Indrio F, Orel R, et al. Commercial probiotic products: A call for improved quality control. A Position Paper by the ESPGHAN Working Group for Probiotics and Prebiotics. J Pediatr Gastroenterol Nutr 2017; 65: 117-24. [CrossRef]

108. del Carmen S, Martín Rosique R, Saraiva T, Zurita-Turk M, Miyoshi A, Azevedo V, et al. Protective effects of lactococci strains delivering either IL-10 protein or CDNA in a TNBS-induced chronic colitis model. J Clin Gastroenterol 2014; 48: 12-7. [CrossRef]

109. Xu LZ, Yang LT, Qiu SQ, Yang G, Luo XQ, Miao BP, et al. Combination of specific allergen and probiotics induces specific regulatory $B$ cells and enhances specific immunotherapy effect on allergic rhinitis. Oncotarget 2016; 7: 54360-9. [CrossRef]

110. Moussu H, Van Overtvelt L, Horiot S, Tourdot S, Airouche S, Zuercher A, et al. Bifidobacterium bifidum NCC 453 promotes tolerance induction in murine models of sublingual immunotherapy. Int Arch Allergy Immunol 2012; 158: 35-42. [CrossRef]

111. Van Overtvelt L, Moussu H, Horiot S, Samson S, Lombardi V, Mascarell L, et al. Lactic acid bacteria as adjuvants for sublingual allergy vaccines. Vaccine 2010; 28: 2986-92. [CrossRef]

112. de Moreno de LeBlanc A, Del Carmen S, Chatel JM, Azevedo V, Langella $P$, Bermudez-Humaran L, et al. Evaluation of the biosafety of recombinant lactic acid bacteria designed to prevent and treat colitis. J Med Microbiol 2016; 65: 1038-46. [CrossRef]

113. Adel-Patient K, Ah-Leung S, Creminon C, Nouaille S, Chatel JM, Langella $P$, et al. Oral administration of recombinant Lactococcus lactis expressing bovine beta-lactoglobulin partially prevents mice from sensitization. Clin Exp Allergy 2005; 35: 539-46. [CrossRef]

114. Bermúdez-Humarán LG, Aubry C, Motta JP, Deraison C, Steidler L, Vergnolle $\mathrm{N}$, et al. Engineering lactococci and lactobacilli for human health. Curr Opin Microbiol. 2013; 16: 278-83. [CrossRef]

Cite this article as: Özdemir Ö. Role and Use of Probiotics in Allergic Diseases: Review of the Literature. İstanbul Med J 2018; 19: 95-104. 